\title{
McCune-Albright syndrome, a rare form of precocious puberty: diagnosis, treatment, and follow-up
}

\author{
Mirta Gryngarten, M.D. ${ }^{a}$, Haydeé Comar, M.D. ${ }^{b}$, Andrea Arcari, M.D. ${ }^{a}$, \\ Elisabeth Boulgourdjian, M.D. ${ }^{a}$ and María E. Escobar, M.D. ${ }^{a}$
}

Collaborator: Horacio Domené, Ph.D.c

a. Center for Endocrinological Research (Centro de Investigaciones Endocrinológicas, CEDIE) “Dr. César Bergadá", National Scientific and Technical Research Council (Consejo Nacional de Investigaciones Científicas y Técnicas, CONICET).

Pediatric Endocrinology Foundation (Fundación de Endocrinología Infantil, FEI). Department of Endocrinology, Hospital de Niños Ricardo Gutiérrez, Autonomous City of Buenos Aires, Argentina.

b. Melipal Children's Center (Centro Pediátrico Melipal, CPM), San Carlos de Bariloche, Argentina.

c. Center for Endocrinological Research (Centro de Investigaciones Endocrinológicas, CEDIE) “Dr. César Bergadá".

E-mail address:

Haydeé Comar, M.D.: haydeecomar@gmail. com

Funding:

None.

Conflict of interest: None.

Received: 12-1-2020 Accepted: 4-12-2021

\begin{abstract}
Introduction. McCune-Albright syndrome (MAS) is a genetic disorder defined by fibrous dysplasia of bone, café-au-lait skin spots, and autonomous hyperfunction of one or more endocrine organs. MAS is caused by activating mutations of the GNAS1 gene. The most frequent type of endocrinopathy is gonadal endocrinopathy in the form of peripheral precocious puberty.

Objective. To describe the clinical characteristics, laboratory and imaging tests at the time of diagnosis and over the course of the disease, focusing on the classical triad of MAS.

Population and methods. Observational, descriptive, retrospective clinical study of patients with MAS seen at the Department of Endocrinology of Hospital de Niños Ricardo Gutiérrez between 1974 and 2019.

Results. Twelve girls are described, all of whom developed peripheral precocious puberty (PPP) secondary to functional ovarian cysts. Their age at presentation was early ( $2.6 \pm 1.3$ years). Gonadotropin levels were suppressed or in the prepubertal range with generally high estradiol levels. Ten girls had café-au-lait skin spots since birth. During the course of disease, polyostotic fibrous dysplasia was detected in all patients. The treatments used to reduce ovarian cyst recurrence and hyperestrogenism effects showed varied effectiveness.

Conclusions. In this series, the onset of PPP helped to make an early diagnosis of MAS and was difficult to treat. The course of disease showed persistent gonadal hyperfunction and worsening of bone injuries.

Key words: McCune-Albrightsyndrome, precocious puberty, fibrous dysplasia of bone.
\end{abstract}

http: / / dx.doi.org/10.5546/ aap.2021.eng.e420

To cite: Gryngarten M, Comar H, Arcari A, Boulgourdjian E, Escobar ME. McCune-Albright syndrome, a rare form of precocious puberty: diagnosis, treatment, and follow-up. Arch Argent Pediatr 2021;119(5):e420-e427.

\section{Acronyms and abbreviations}

CPP: central precocious puberty. E2: estradiol.

FDB: fibrous dysplasia of bone.

FSH: follicle-stimulating hormone.

$\mathrm{GH}$ : growth hormone.

GnRH: gonadotropin-releasing

hormone.

IFMA: immunofluorometric assay.

LH: luteinizing hormone.

MAS: McCune-Albright syndrome.

MPH: midparental height.

PP: precocious puberty.

PPP: peripheral precocious puberty.

RIA: radioimmunoassay.

\section{INTRODUCTION}

Precocious puberty in girls is defined as the onset of pubertal development before 8 years of age. ${ }^{1}$ Two types of precocious puberty (PP) have been established based on their originating mechanism: central precocious puberty (CPP), caused by the early activation of the hypothalamic-pituitarygonadal (HPG) axis, and peripheral precocious puberty (PPP), caused by an autonomous gonadal activity. One of the etiologies of PPP is McCuneAlbright syndrome (MAS), which is accompanied by the involvement of different organs and systems.

MAS was first described in 1936 by Donovan McCune $^{2}$ and in 1937 by Fuller Albright. ${ }^{3}$ The association of precocious puberty, fibrous dysplasia of bone (FDB), and café-au-lait skin spots is currently known as the typical MAS triad.$^{4-6}$ It may be associated with different endocrinopathies and other organ involvement..$^{6-8}$ MAS prevalence 
ranges from $1 / 100000$ to $1 / 1000000$ in the general population. ${ }^{4}$ It is a sporadic disorder caused by a postzygotic activating mutation of the GNAS1 gene that codes the stimulatory G protein $\alpha$-subunit (Gs $\alpha$ ), leading to constitutive activation of adenylyl cyclase with unrestricted production and excess intracellular cAMP, hyperplasia, and uncontrolled secretion of cell products. ${ }^{9,10}$

The most frequent type of endocrinopathy is gonadal endocrinopathy in the form of PPP. Although male and female children may be affected, a significantly higher prevalence has been described in girls, with a 9:1 ratio. ${ }^{11-14}$ The autonomous activation of the ovary leads to the intermittent development of follicular cysts, which cause varying levels of estradiol and clinical signs of hyperestrogenism. Some girls may secondarily develop CPP.

Different treatments have been used to manage MAS, aimed at reducing the recurrence of ovarian cysts, counteracting the manifestations of estrogen excess, and stopping the advancement of bone injuries. ${ }^{13}$

The objective of this study was to describe the clinical characteristics and supplementary tests in a cohort of girls with MAS, the effectiveness of different treatments, and the long-term course of patients.

\section{POPULATION AND METHODS}

This was an observational, descriptive, retrospective clinical study carried out at the Department of Endocrinology of Hospital de Niños Ricardo Gutiérrez (HNRG). The medical records of girls with MAS seen between 1974 and 2019 were analyzed, at the time of diagnosis and over the course of their condition until adolescence. Inclusion criteria: MAS showing the triad of PPP, café-au-lait skin spots, and FDB or MAS with only two manifestations. Exclusion criteria: Girls with recurrent ovarian cysts, with no other syndrome components.

The following were analyzed: age at onset of the first sign of puberty, vaginal bleeding (VB), café-au-lait skin spots, anthropometric data, age at menarche, menstrual cycle alterations, bone alterations, and final height compared to midparental height (MPH). Lab tests, estradiol (E2), FSH, and LH at baseline and after GnRH stimulation were done using a RIA until 1994 and an IFMA thereafter. A serum E2 level $\geq 14 \mathrm{pg} / \mathrm{mL}^{15}$ with both methods was considered indicative of puberty. ${ }^{16}$ Gonadotropin levels assessed by RIA or IFMA were considered inhibited if the baseline and/or post-GnRH stimulation values were $<2$ standard deviations (SD) of the normal pre-pubertal values for the assay used. ${ }^{17,18}$

The molecular analysis to detect the GNAS1 gene mutation was done in DNA from peripheral blood and tissue using the allele-specific polymerase chain reaction (AS-PCR). ${ }^{19}$

The following imaging tests were done: pelvic ultrasound, $x$-ray for bone age (BA), bone scan, others (bone x-rays, CAT scan, MRI) based on clinical data.

Results are expressed as mean and SD or median $\left(\mathrm{M}_{\mathrm{e}}\right)$ and range. Wilcoxon's test was used for paired samples to assess treatment outcomes. Auxological data were unified by translating them into a SD score (SDS) based on the Argentine reference tables by Lejarraga et al. ${ }^{20}$

The study was approved by the Research Ethics Committee (REC approval no.: 14.48) and the Research and Teaching Committee of HNRG. The principles established in the World Medical Association's Declaration of Helsinki and Law 3301/ 09 for the Protection of the Rights of Health Research Subjects of the Autonomous City of Buenos Aires were met.

\section{RESULTS}

Ten patients showed the typical MAS triad, while 2 had MAS with 2 manifestations (Table 1).

\section{Diagnosis and management}

In all patients, the first manifestation of disease was precocious puberty at an onset age (mean \pm SD) of $1.8 \pm 1.3$ years. Chronological age (CA) at diagnosis was $2.3 \pm 1.3$ years, while BA was $3.7 \pm 1.6$ years. BA was advanced in 6 girls, whereas the rest had a BA that matched their CA. The first sign was simultaneous breast development (thelarche) and vaginal bleeding in $9 / 12$ patients (Table 2 ). In $8 / 12$ patients, unilateral ovarian cysts with a diameter between 29 and

TABLE 1. Clinical manifestations

\begin{tabular}{lc}
\hline Clinical manifestations & n: $\mathbf{1 2}$ \\
\hline Fibrous dysplasia of bone & 12 \\
Precocious puberty & 12 \\
Café-au-lait skin spots & 10 \\
Hyperthyroidism & 2 \\
Growth hormone hypersecretion & 2 \\
Hyperprolactinemia & 2 \\
\hline
\end{tabular}


$53 \mathrm{~mm}$ were observed. E2 and gonadotropin levels are shown in Table 3. Serum E2 values ranged between undetectable $(<10 \mathrm{pg} / \mathrm{ml})$ and $90 \mathrm{pg} / \mathrm{ml}$. In 3 patients whose ultrasound did not show ovarian cysts, high E2 levels were observed. In 9 girls, serum gonadotropins were determined after GnRH stimulation and the value was prepubertal or inhibited, whereas only baseline levels were determined in 3 girls, who had an inhibited value, thus confirming their PPP diagnosis. Six patients had a molecular analysis done in peripheral blood samples; the mutation was detected in 2 girls who had the typical MAS triad. In 1 of them, several samples were obtained for surgery and the mutation was found in her skin, muscle, bone, and thyroid tissue.

Data related to PPP treatment are shown in Figure 1. The first line of treatment in all girls were weekly medroxyprogesterone acetate (MPA) injections for $6.1 \pm 2.6$ years. Tamoxifen was administered to 3 patients for 1.2 to 2.4 years. With the emergence of aromatase inhibitors, MPA was interrupted in 2 girls and treatment with testolactone for 8 and 15 months, respectively, was started; this was later interrupted due to unavailability of the drug and MPA was restarted.

TABLE 2. Stage of precocious puberty diagnosis: Clinical characteristics

\begin{tabular}{|c|c|c|c|c|c|c|c|c|}
\hline Patient & $1^{\text {st }}$ sign & $\begin{array}{c}\text { CA at } 1^{\text {st }} \text { sign } \\
\text { (years) }\end{array}$ & $\begin{array}{c}\text { CA at } 1^{\text {st }} \text { visit } \\
\text { (years) }\end{array}$ & $\begin{array}{l}\text { BA-CA } \\
\text { (years) }\end{array}$ & $\begin{array}{c}\text { Tanner } \\
\text { stage }\end{array}$ & $\begin{array}{c}\text { Vaginal } \\
\text { bleeding }\end{array}$ & $\begin{array}{c}\text { Café-au-lait } \\
\text { skin spots }\end{array}$ & $\begin{array}{c}\text { Fibrous } \\
\text { dysplasia }\end{array}$ \\
\hline 1 & Thelarche + VB & 1.5 & 4 & 2 & B3 PH1 & + & - & + \\
\hline 2 & Thelarche + VB & 1.2 & 1.3 & 1.3 & B3 PH1 & + & + & + \\
\hline 3 & VB & 0.5 & 4.3 & 1.6 & B3 PH1 & + & - & + \\
\hline 4 & Thelarche + VB & 0.8 & 1.3 & 1.3 & B3 PH1 & + & + & + \\
\hline 5 & Thelarche + VB & 0.5 & 1 & 1.5 & B3 PH1 & + & + & + \\
\hline 6 & Thelarche + VB & 0.8 & 0.8 & 0.1 & B3 PH1 & + & + & + \\
\hline 7 & VB & 1 & 2.2 & 1.7 & B3 PH1 & + & + & + \\
\hline 8 & Thelarche + VB & 2 & 2.1 & 1.3 & B3 PH1 & + & + & + \\
\hline 9 & Thelarche + VB & 4.1 & 4.1 & 1.7 & B3 PH1 & + & + & + \\
\hline 10 & Thelarche & 4.5 & 4.5 & 0.5 & B3 PH2 & - & + & + \\
\hline 11 & Thelarche + VB & 2.3 & 2.6 & 0.1 & B3 PH1 & + & + & + \\
\hline \multirow[t]{3}{*}{12} & Thelarche + VB & 3.1 & 3.1 & 0.4 & B3 PH2 & + & + & + \\
\hline & Mean & 1.8 & 2.6 & 1.1 & & & & \\
\hline & SD & 1.3 & 1.3 & 0.6 & & & & \\
\hline
\end{tabular}

VB: vaginal bleeding, CA: chronological age, BA: bone age, SD: standard deviation, B: breast, PH: pubic hair.

FIGURE 1. Course of precocious puberty with different treatments

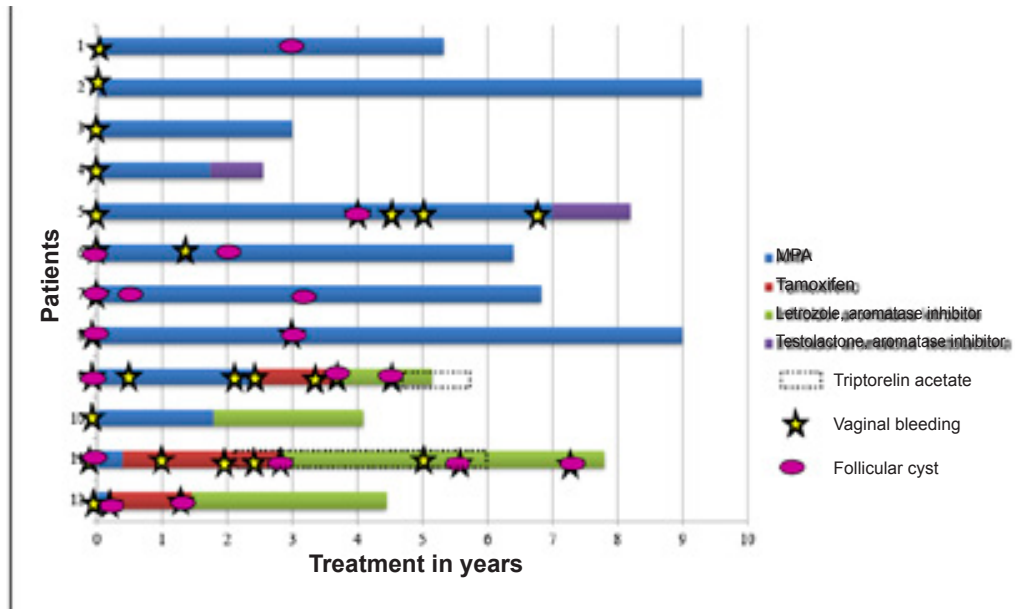

MPA: medroxyprogesterone acetate. 
Four patients received a third-generation inhibitor, letrozole, for 1.5 to 5 years.

Out of the 12 girls, 6 did not have VB while treated with MPA, $2 / 3$ had VB while receiving tamoxifen, and 2/4, while taking letrozole. Among those with VB while being treated, ovarian cysts were observed by ultrasound at that time. Two girls underwent a laparoscopic cystectomy. One patient had a unilateral oophorectomy at 1 year old due to large ovary size, abdominal pain, and risk for torsion. Later, she developed recurrent cysts in the remaining ovary. Two patients progressed to CPP and started treatment with a GnRH analog for 2 and 4.3 years, respectively.

All patients showed evidence of polyostotic FDB. Repeated pathological fractures were reported in 9 girls between 2 and 9 years old, and skull compromise with hyperostotic injuries involving the skull base. As a result of cranial nerve compression, 1 girl showed hearing involvement and 1, visual compromise. FDB affected only the limbs in 3 girls, evidenced as hypostotic, cystic or ground-glass lesions. Seven girls required surgical treatment and 2, decompression surgery of craniofacial injuries and plastic surgery due to severe facial asymmetry.

Due to persistent pain, 6 patients were treated with pamidronate, which relieved pain, but had no effect on bone disease progression. Four patients developed lower limb shortening and bowing with final height compromise.
Skin spots were observed in 10/12 girls since birth. Skin spots had rough borders, corresponding to the "coast of Maine" pattern, and did not change in terms of number or characteristics over time.

\section{Long-term follow-up}

In spite of their treatment for PPP, 2 girls developed recurrent ovarian cysts and progressed to secondary CPP. Patients interrupted their treatment for PPP at a CA $\left(\mathrm{M}_{\mathrm{e}}\right)$ of 9.8 years (8.5-11.9). Ten girls had menarche at a CA $\left(\mathrm{M}_{\mathrm{e}}\right)$ of 11.1 years and 1.3 years after treatment discontinuation (Table 4). Patient 12 is still receiving letrozole. The median adult height was $150.5 \mathrm{~cm}(122-174 \mathrm{~cm})$, significantly lower than MPH $(p<0.05)$. Six patients did not reach $\mathrm{MPH}$. In the case of patient 2, her shortest final height was related to severe FDB associated with multiple fractures and lower limb deformities (Table 4).

Five patients had persistent irregular menstrual cycles after 3 years of gynecological age (polymenorrhea, oligomenorrhea, and secondary amenorrhea). Recurrent ovarian cysts after menarche were observed in 4 patients in association with inhibited gonadotropin values, indicative of persistent autonomous ovarian activity. Cysts disappeared spontaneously, as confirmed by gynecological ultrasound.

All patients showed progressive worsening of bone injuries.

TABLE 3. Stage of diagnosis: Ovarian cyst and serum hormone levels at baseline and after GnRH stimulation

\begin{tabular}{|c|c|c|c|c|c|c|c|}
\hline \multirow[b]{2}{*}{ Patient } & \multirow[b]{2}{*}{$\begin{array}{c}\text { Cyst } \\
\text { Largest diameter }\end{array}$} & \multirow[b]{2}{*}{$\begin{array}{c}\text { Estradiol } \\
(\mathrm{pg} / \mathrm{ml})\end{array}$} & \multicolumn{4}{|c|}{ GnRH stimulation test } & \multirow[b]{2}{*}{$\begin{array}{c}\text { Gonadotropin } \\
\text { assay }\end{array}$} \\
\hline & & & $\begin{array}{c}\text { Baseline LH } \\
\text { (mIU/ml) }\end{array}$ & $\begin{array}{l}\text { Max. LH } \\
(\mathrm{mIU} / \mathrm{ml})\end{array}$ & $\begin{array}{c}\text { Baseline FSH } \\
(\mathrm{mIU} / \mathrm{ml})\end{array}$ & $\begin{array}{c}\text { Max. FSH } \\
(\mathrm{mIU} / \mathrm{ml})\end{array}$ & \\
\hline 1 & No & 70 & 2 & 13.6 & 3.1 & 10.4 & RIA \\
\hline 2 & LO $32 \mathrm{~mm}$ & 30 & 6 & 5.2 & 1.3 & 1.9 & RIA \\
\hline 3 & $\mathrm{RO} 31 \mathrm{~mm}$ & 45 & $<2$ & -- & $<1$ & -- & RIA \\
\hline 4 & LO $52 \mathrm{~mm}$ & 11 & 2.4 & 4.2 & 12 & 21 & RIA \\
\hline 5 & No & 60 & 3.3 & 3.9 & 1.2 & 3.5 & RIA \\
\hline 6 & LO $29 \mathrm{~mm}$ & 90 & $<1$ & $<1$ & $<1$ & $<1$ & RIA \\
\hline 7 & Micro-multifollicular & 60 & $<1$ & 14.5 & $<1$ & 13.1 & RIA \\
\hline 8 & $\mathrm{RO} 30 \mathrm{~mm}$ & 44 & 0.05 & 0.54 & 0.8 & 3.8 & IFMA \\
\hline 9 & LO $30.4 \mathrm{~mm}$ & 33 & 0.1 & & 0.27 & & IFMA \\
\hline 10 & $\mathrm{RO} 36 \mathrm{~mm}$ & 28.4 & 0.1 & 1.65 & 0.37 & 3.76 & IFMA \\
\hline 11 & $\mathrm{RO} 18 \mathrm{~mm}$ & 28 & $<0.1$ & 1 & 0.27 & 2.74 & IFMA \\
\hline 12 & $\mathrm{RO} 36 \mathrm{~mm}$ & 29 & 0.1 & & 0.15 & & IFMA \\
\hline
\end{tabular}

GnRH: gonadotropin-releasing hormone, RIA: radioimmunoassay, IFMA: immunofluorometric assay, RO: right ovary, LO: left ovary. 


\section{DISCUSSION}

$\mathrm{PP}$ and FDB are the most common alterations observed in MAS. . $-5,13,21^{2}$

PPP is caused by autonomous gonadal hyperfunction, with typical clinical manifestations different from those of CPP. Whereas, in the case of CPP, the age at onset is usually closer to that of normal puberty and development progresses similarly, in PPP the age at the onset of the first sign is very early, usually $\mathrm{VB}$, which may occur before or at the same time as thelarche, with little acceleration of growth rate and BA as a result of the fast onset of PP. . $^{4,6,12}$ Ultrasound observation of ovarian cysts, which disappear spontaneously, and their recurrence accompanied by repeated clinical signs guide diagnosis, as in the case of all the patients in this study. The confirmation of the peripheral nature of PP is done based on gonadotropin levels at baseline or after GnRH stimulation, which are low or inhibited, and serum estradiol levels, with varying values, as observed in this study. With the resolution of ovarian cysts, estradiol levels decrease rapidly, whereas gonadotropin inhibition may last; this may be the reason for the disagreement observed in some cases. ${ }^{22}$ PPP usually has an intermittent course with long remission periods; however, some patients have rapid progression, accelerated growth, and skeletal maturation, affecting their final height. ${ }^{5,6,12}$ As a result of sustained or repeated exposure to high estradiol levels from follicular cysts, CPP may develop secondary to the early activation of the HPG axis, ${ }^{4,11,12}$ as observed in 2 girls from our series. The diagnosis of PPP in relation to MAS is clinical when the typical triad of symptoms is observed. In the case of apparent absence of bone alterations, a bone scan with Tc99 is recommended, as done

TABLE 4. Long-term follow-up of patients with PPP due to MAS

\begin{tabular}{|c|c|c|c|c|c|c|c|c|c|}
\hline Patient (n) & $\begin{array}{c}\text { Age at } \\
\text { diagnosis } \\
\text { of PP years }\end{array}$ & $\begin{array}{c}\text { CA at } t x \\
\text { initiation for } \\
\text { PP years }\end{array}$ & $\begin{array}{c}\text { BA-CA } \\
\text { years at } \\
\text { tx initiation }\end{array}$ & $\begin{array}{c}\text { Height at } \\
\text { tx initiation } \\
\mathrm{cm}(\mathrm{SD})\end{array}$ & $\begin{array}{c}\text { CA at tx } \\
\text { interruption } \\
\text { years }\end{array}$ & $\begin{array}{c}\text { BA-CA at tx } \\
\text { interruption } \\
\text { years }\end{array}$ & $\begin{array}{c}\text { Menarche } \\
\text { years }\end{array}$ & $\begin{array}{c}\text { Final heigh } \\
\mathrm{cm} \\
\text { (SD) }\end{array}$ & $\begin{array}{l}\mathrm{MPH} \\
\mathrm{cm} \\
(\mathrm{SD})\end{array}$ \\
\hline 1 & 4 & 4.5 & 1.3 & $\begin{array}{l}107 \\
(0.8)\end{array}$ & 9.6 & 1.3 & 10.5 & $\begin{array}{l}144.8 \\
(-2.6)\end{array}$ & $\begin{array}{c}157 \\
(-0.6)\end{array}$ \\
\hline 2 & 1.4 & 2.5 & 1.53 & $\begin{array}{c}90 \\
(0.1)\end{array}$ & 11.7 & 1.3 & 12.9 & $\begin{array}{c}122 \\
(-6.3)\end{array}$ & $\begin{array}{c}157.5 \\
(-0.52)\end{array}$ \\
\hline 3 & 4.4 & 6.0 & 1.37 & $\begin{array}{c}128.7 \\
(2.9)\end{array}$ & 9 & 1.4 & 11.9 & $\begin{array}{l}174 \\
(2.1)\end{array}$ & $\begin{array}{l}171.7 \\
(1.81)\end{array}$ \\
\hline 4 & 1.4 & 5.2 & 1.54 & $\begin{array}{l}118.1 \\
(0.8)\end{array}$ & 9.0 & 1.5 & 9.9 & $\begin{array}{l}148 \\
(-2)\end{array}$ & $\begin{array}{c}161 \\
(0.04)\end{array}$ \\
\hline 5 & 1 & 1.0 & 3 & $\begin{array}{c}79 \\
(1.1)\end{array}$ & 9.4 & 1.4 & 12.0 & $\begin{array}{c}151 \\
(-1.5)\end{array}$ & $\begin{array}{l}168.5 \\
(1.27)\end{array}$ \\
\hline 6 & 0.8 & 2.1 & 1.9 & $\begin{array}{c}92 \\
(1.5)\end{array}$ & 8.5 & 1.35 & 10 & $\begin{array}{l}157.5 \\
(-0.5)\end{array}$ & $\begin{array}{c}157.5 \\
(-0.52)\end{array}$ \\
\hline 7 & 2.3 & 3.1 & 1.25 & $\begin{array}{l}106 \\
(2.8)\end{array}$ & 10 & 1.2 & 10.8 & $\begin{array}{c}150 \\
(-1.7)\end{array}$ & $\begin{array}{l}161.5 \\
(0.13)\end{array}$ \\
\hline 8 & 2.2 & 2.1 & 1.59 & $\begin{array}{l}89.5 \\
(0.7)\end{array}$ & 12 & 1.1 & 15.5 & $\begin{array}{l}142 \\
(-3)\end{array}$ & $\begin{array}{c}159 \\
(0.27)\end{array}$ \\
\hline 9 & 4.2 & 4.9 & 1.1 & $\begin{array}{l}113.5 \\
(1.8)\end{array}$ & 12.5 & 2.4 & 11.1 & $\begin{array}{l}158.5 \\
(-0.3)\end{array}$ & $\begin{array}{l}162.5 \\
(0.29)\end{array}$ \\
\hline 10 & 4.9 & 6.7 & 2 & $\begin{array}{l}124.7 \\
(0.2)\end{array}$ & 10.9 & 1.3 & -- & $\begin{array}{l}153.5 \\
(-1.1)\end{array}$ & $\begin{array}{l}163 \\
(0.3)\end{array}$ \\
\hline 11 & 2.9 & 3.9 & 1 & $\begin{array}{l}100.1 \\
(0.4)\end{array}$ & 11.9 & 1.4 & 11.6 & $\begin{array}{c}153 \\
(-1.2)\end{array}$ & $\begin{array}{c}159 \\
(0.27)\end{array}$ \\
\hline $\begin{array}{l}\text { Median } \\
\text { Range }\end{array}$ & $\begin{array}{c}2.2 \\
(0.8-4.9)\end{array}$ & $\begin{array}{c}3.5 \\
(1.0-6.7)\end{array}$ & $\begin{array}{l}1.45 \\
(1-3)\end{array}$ & $\begin{array}{c}103 \\
(79-124.7)\end{array}$ & $\begin{array}{c}9.8 \\
(8.5-11.9)\end{array}$ & $\begin{array}{c}\mathbf{1 . 3} \\
(1.1-1.5)\end{array}$ & $\begin{array}{c}\mathbf{1 1 . 1} \\
(10-15.5)\end{array}$ & $\begin{array}{c}150.5 \\
(122-174)\end{array}$ & $\begin{array}{c}160 \\
(157-171.7\end{array}$ \\
\hline
\end{tabular}

PPP: peripheral precocious puberty, MAS: McCune-Albright syndrome, BA: bone age, CA: chronological age, SD: standard deviation, MPH: midparental height. 
in all our patients. If increased uptake areas are observed, a localized x-ray of the area should be done to accurately establish the injury. In case of an uncertain diagnosis, a molecular analysis may be done for the mutation. In this study, it was not possible to perform a molecular analysis in all patients. The mutation is found in more than $90 \%$ of analyses performed in affected tissues, regardless of the clinical presentation. However, when done in peripheral blood samples, detection is much lower, and even lower if the patient does not show the typical MAS triad. ${ }^{10}$

Different treatments have been used to reduce ovarian cyst development and the effects of hyperestrogenism, with varying degrees of effectiveness. Although MPA may inhibit $\mathrm{VB}$, it has not demonstrated an effect on bone maturation. ${ }^{23,24}$ Tamoxifen, a selective estrogen receptor modulator, was administered to 25 girls and showed a reduction in VB events and an adequate control of growth rate and bone maturation, although it had no effect on ovarian volume and uterine size. ${ }^{24}$ Another study carried out in 8 girls treated for 3-8 years achieved the interruption of $\mathrm{VB}$, the stabilization of skeletal maturation, and an improved prediction of final height. ${ }^{25}$ Letrozole, a third-generation aromatase inhibitor, is considered useful in the treatment of PPP. A study conducted in 9 girls reduced the rate of $\mathrm{VB}$, the growth rate, and the advancement of BA. Only 1 patient developed an ovarian cyst under treatment. ${ }^{26}$ Estrada et al. published a long-term, retrospective study with letrozole administered to 28 girls. The treatment was effective to reduce the growth and skeletal maturation rates and to improve adult height prediction. ${ }^{27}$ For girls who fail to respond to drug treatment, surgical resection of persistent ovarian cysts by laparoscopic cystectomy may help to control PPP. ${ }^{28}$ All our patients received MPA, which was the only treatment available until 1987. They had a favorable response in relation to the number of VB events, probably due to the anti-estrogenic activity of this progestin on the endometrium, ${ }^{23}$ but did not show a slowdown of BA. It is not possible to draw conclusions about the new treatment initiated in our series due to the reduced number of treated patients.

There is little information about the course of ovarian function during adolescence and adulthood. As observed in our patients, ovarian autonomy episodes may persist, manifested by menstrual cycle disorders, cyst development, and high estradiol levels with pre-pubertal or inhibited gonadotropin values..$^{29,30}$ Sotomayor et al. found a significantly lower proportion of ovulatory cycles in patients with MAS compared to normal controls. ${ }^{31}$

FDB is usually unilateral and generally polyostotic. ${ }^{32,33}$ The skull base and long bones are more frequently affected. X-rays show cystic or lytic lesions, and "ground-glass" lesions are typical in children. ${ }^{21,32}$ Pathological fractures and deformities may also be observed, e.g., in the femur ("shepherd's crook"). ${ }^{21}$ Initial manifestations include pain, limb claudication or pathological fracture. The incidence is higher between 5 and 10 years old. ${ }^{19,33}$ Pamidronate has been used in cases of severe pain, administered orally to 4 patients and intravenously to 2 patients. ${ }^{34,35}$ When the long bones are affected, surgery with intramedullary implants is recommended..$^{21,33} \mathrm{All}$ our patients developed FDB; most of them had fractures and many required surgery. Lumps in the face and skull or facial asymmetry are observed. Excess GH levels are associated with fibrous dysplasia in the skull base $^{8,21}$ and reduced visual and hearing acuity due to cranial nerve compression.

Café-au-lait skin spots are very common and typical of MAS and are present since birth, although they are not considered pathological until other MAS features develop, ${ }^{4}$ as observed in our patients, who sought care due to PPP signs. Café-au-lait skin spots are caused by melanocytic proliferation, are benign and lack the potential to progress to malignancy, ${ }^{5,36}$ appear in varying numbers and shapes, almost always have rough borders ("coast of Maine"), and become more evident with exposure to sunlight. They are limited to one side of the body, in general do not cross the midline of the body, and do not change over the course of disease, as observed in our patients. Café-au-lait skin spots are distributed following Blaschko's lines, which account for the migration pattern of ectodermal cells during the embryonic stage. ${ }^{5,36}$

PPP associated to MAS is an uncommon condition. In general, it is diagnosed during childhood, but the onset of other syndrome features, such as bone dysplasia and other types of endocrine hyperfunction, usually occurs later and in a progressive manner, so it is necessary for these patients to be under continuous clinical surveillance.

\section{CONCLUSIONS}

In our patients, the onset of PPP helped to make an early diagnosis of MAS and was 
difficult to manage with the different treatments in place. In the long term, persistent gonadal hyperfunction and worsening of bone injuries were confirmed. Given its complexity, MAS requires a multidisciplinary approach.

\section{REFERENCES}

1. Grumbach MM, Styne DM. Puberty: Ontogeny, neuroendocrinology, physiology and disorders. In: Wilson JD, Foster DW, Kronenberg HM, Larsen PR. Williams Textbook of Endocrinology. $9^{\text {th }}$ ed. Philadelphia:Saunders; 1998.Pages.1509-625.

2. McCune DJ. Osteitis fibrosa cystica: the case of a nine-year old girl who also exhibits precocious puberty, multiple pigmentation of the skin and hyperthyroidism. Am J Dis Child. 1936; 52:743-4.

3. Albright F, Butler AM, Hampton AO, Smith P. Syndrome characterized by osteitis fibrosa disseminata, areas of pigmentation, and endocrine dysfunction, with precocious puberty in females: report of 5 cases. N Engl J Med. 1937; 216(17):727-46.

4. Dumitrescu CE, Collins MT. McCune-Albright syndrome. Orphanet J Rare Dis. 2008; 3:12.

5. Collins MT, Singer FR, Eugster E. McCune-Albright syndrome and the extraskeletal manifestations of fibrous dysplasia. Orphanet J Rare Dis. 2012; 7(Suppl 1):S4.

6. Tufano M, Ciofi D, Amendolea A, Stagi S. Auxological and Endocrinological Features in Children with McCune AlbrightSyndrome: A Review. Front Endocrinol (Lausanne). 2020; 11:522.

7. Congedo V, Celi FS. Thyroid disease in patients with McCune-Albright syndrome. Pediatr Endocrinol Rev. 2007; 4(Suppl 4):429-33.

8. SalenaveS, Boyce AM, Collins MT, Chanson P. Acromegaly and McCune-Albright syndrome. J Clin Endocrinol Metab. 2014; 99(6):1955-69.

9. Weinstein LS, Yu S, Warner DR, Liu J. Endocrine manifestations of stimulatory $G$ protein alpha-subunit mutations and the role of genomic imprinting. Endocr Rev. 2001; 22(5):675-705.

10. Lumbroso S, Paris F, Sultan C, European Collaborative Study. Activating Gs Mutations: Analysis of 113 Patients withSigns of McCune-AlbrightSyndrome. JClin Endocrinol Metab. 2004; 89(5):2107-13.

11. Brito V, Latronico A, Arnhold I, Mendonça BB. Update on the etiology, diagnosis and therapeutic management of sexual precocity. Arq Bras Endocrinol Metab. 2008; 52(1):18-31.

12. Zacharin M. The Spectrum of McCune-Albright syndrome. Ped Endocrinol Rev. 2007; 4(Suppl 4):412-8.

13. Neyman A, Eugster EA. Treatment of Girls and Boys with McCune-Albright Syndrome with Precocious Puberty Update 2017. Pediatr Endocrinol Rev. 2017; 15(2):136-41.

14. Corica D, Aversa T, Pepe G, De Luca F, Wasniewska M. Peculiarities of Precocious Puberty in Boys and Girls with McCune-Albright Syndrome. Front Endocrinol (Lausanne). 2018; 9:337.

15. Escobar ME, Rivarola MA, BergadáC. Plasma concentration of estradiol-17 $\beta$ in premature thelarche and in different types of sexual precocity. Acta Endocrinol (Copenh). 1976; 81(2):351-61.

16. Ballerini MG, Ropelato MG, Gruñeiro LO, Bozzo G, et al. Estradiol(E2): determinación dela sensibilidad funcional de inmunoensayos radioisotópicos (IEs) y no radioisotópicos. Rev Argent Endocrinol Metab. 1999; 36(Suppl):86.
17. Sizonenko PC, Burr IM, Kaplan SL, Grumbach MM. Hormonal Changes in Puberty II. Correlation of serum luteinizing hormone and follicle stimulating hormone with stages of puberty and bone age in normal girls. Pediatr Res. 1970; 4(1):36-45.

18. Ropelato MG, Escobar ME, Gottlieb S, Bergadá C. Gonadotropin secretion in prepubertal normal and agonadal children evaluated by ultrasensitive time-resolved immunofluorometric assays. Horm Res. 1997; 48(4):164-72.

19. Domené HM, Sansó G, Gryngarten M, Escobar ME. AlleleSpecific Amplification (AS-PCR) for Point Mutation Screening of GProtein $\alpha$-Subunit (Gs $\alpha)$ in McCune-Albright Syndrome (MAS). Pediatr Res. 1999; 45:441.

20. Lejarraga H, Orfila G. Estándares de peso y estatura para niñas y niños argentinos desde el nacimiento hasta la madurez. Arch Argent Pediatr. 1987; 85(4):209-22.

21. Collins MT. Spectrum and natural history of fibrous dysplasia of bone. J Bone Miner Res. 2006, 21(Suppl 2):P99104.

22. SousaGde,WunschR, AndlerW.Precocious pseudopuberty due to autonomous ovarian cysts: A report of ten cases and long-term follow-up. Hormones (Athens). 2008; 7(2):170-4.

23. Murad F, Haynes RC. Estrógenos y Progestágenos. In: Goodman Gilman A, Goodman LS, Rall TW, Murad F. Goodman y Gilman: Las Bases Farmacológicas De La Terapéutica. $7^{\text {a }}$ ed. Buenos Aires; Panamericana; 1986. Pages.1341-65.

24. EugsterEA, RubinSD, ReiterEO, PlourdeP, etal. Tamoxifen treatment for precocious puberty in McCune-Albright syndrome: a multicenter trial. J Pediatr. 2003; 143(1):60-6.

25. Passone CB, Kuperman H, Menezes-Filho HC, Esteves LSO, et al. Tamoxifen Improves Final Height Prediction in Girls with McCune-Albright Syndrome: A Long FollowUp. Horm Res Paediatr. 2015; 84(3):184-9.

26. Feuillan P, Calis K, Hill S, Shawker T, et al. Letrozole treatment of precocious puberty in girls with the McCuneAlbright syndrome: a pilot study. J Clin Endocrinol Metab. 2007; 92(6):2100-6.

27. Estrada A, Boyce A, Brillante B, Guthrie L, et al. Long-term outcomes of letrozole treatment for precocious puberty in girls with McCune-Albright syndrome. Eur J Endocrinol. 2016; 175(5):477-83.

28. Gesmundo R, Guanà R, Valfrè L, De Sanctis L, et al. Laparoscopic management of ovarian cysts in peripheral precocious puberty of McCune-Albrightsyndrome.J Pediatr Endocrinol Metab. 2006; 19(Suppl 2):571-5.

29. Escobar ME, Gryngarten MG, Domenè H, Ropelato MG, et al. Persistence of autonomous ovarian activity after discontinuation of therapy for precocious puberty in McCune-Albright syndrome. I Pediatr Adolesc Gynecol. 1997; 10(3):147-51.

30. Lala R, Andreo M, Pucci A, Matarazzo P. Persistent hyperestrogenism after precocious puberty in young females with McCune-Albright syndrome. Pediatr Endocrinol Rev. 2007; 4(Suppl 4):423-8.

21. SotomayorK, Iñiguez G, UgarteF, VillarroelC, et al. Ovarian function in adolescents with McCune-Albright syndrome. J Pediatr Endocrinol Metab. 2011; 24(7-8):525-8.

32. Riminucci M, Robey PG, Bianco P. The pathology of fibrous dysplasia and the McCune-Albright syndrome. Pediatr Endocrinol Rev. 2007; 4(Suppl 4):401-11.

33. Boyce AM, Collins MT. Fibrous Dysplasia/McCuneAlbright syndrome: a rare, mosaic disease of $\mathrm{G} \alpha$ s activation. Endocr Rev. 2020; 41(2):345-70.

34. Majoor BC, Appelman-Dijkstra NM, Fiocco M, van de 
Sande MA, et al. Outcome of long-term bisphosphonate therapy in McCune-Albright syndrome and polyostotic fibrous dysplasia. J Bone Miner Res. 2017; 32(2):264-76.

35. Lala R, Matarazzo P, Andreo M, Marzari D, et al. Bisphosphonate treatment of bone fibrous dysplasia in
McCune-Albrightsyndrome. JPediatr Endocrinol Metab. 2006; 19(Suppl 2):583-93.

36. Shah KN. The diagnostic and clinical significance of caféau-lait macules. Pediatr Clin North Am. 2010; 57(5):1131-53. 